\section{Notas sobre la memoria, la nostaloia y la poesía}

\author{
Aída Chacón-Castellanos
}

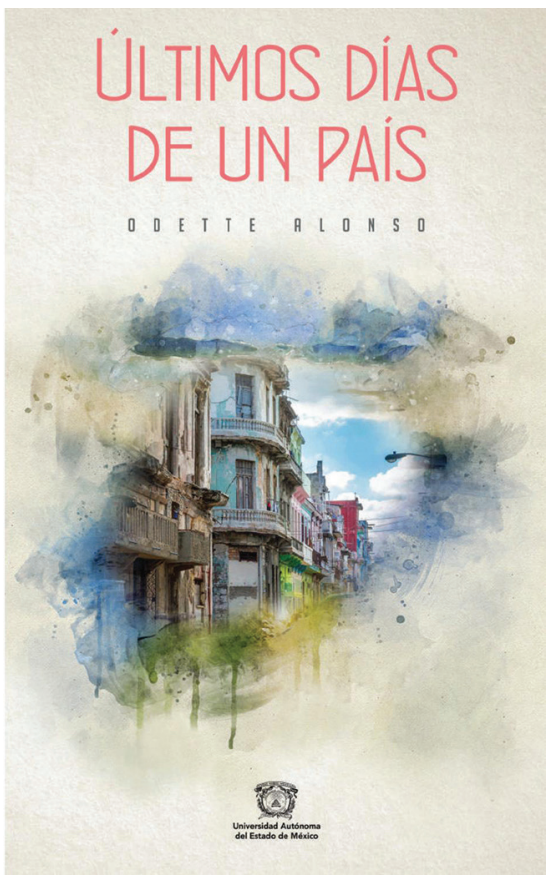

Odette Alonso, Últimos días de un país, ISBN 978-607-633-057-9, México, Universidad Autónoma del Estado de México, 2019, 57 pp.
Mi país es ese instante único que ahora mismo sucede en todas partes. Albis Torres

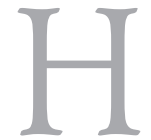
ablar de literatura cubana implica, desde hace ya algunas décadas, una cuestión de geografías reales y simbólicas cuyas fronteras se han mudado fuera de los confines de la isla. Los caminos para la escritura se han abierto más allá del triunfo de la revolución, su construcción, consolidación y las constantes fracturas que ha sufrido a lo largo de medio siglo de historia.

Dicha particularidad permite, a la luz del presente, ir armando un rompecabezas que ayuda a comprender las distintas visiones que giran en torno al tema central de esta literatura: Cuba, su revolución, su geografía, su historia. Esta cualidad, aunque no resulta una versión polifónica de los acontecimientos, tal como propone Svetlana Alexievich en La guerra no tiene rostro de mujer (1985), sí nos brinda un cúmulo de experiencias y puntos de vista que, en conjunto, logra reconstruir un capítulo de la historia de América Latina y el mundo, cuya influencia social ha sido innegable.

Por estas razones, me permito centrarme en una postura transfronteriza y señalo una visión evocadora de una historia íntima que se hace colectiva al estar atravesada por temas que son humanos y vigentes: migración forzada, exilio, búsqueda de raíces nuevas, esperanza.

Estos tópicos universales resultan también consonantes con la historia actual de casi todos los rincones de la Tierra. No hay un país que no viva las consecuencias de la migración; no hay sociedad que no las sienta. Este clima se nutre de las impresiones que migran de lo público a lo privado, y de vuelta, para conmocionarnos.

Últimos días de un país, de Odette Alonso, es el poemario ganador del premio Clemencia Isaura 2019. La autora, de origen cubano, ha echado raíces en México, y esta identidad, formada de fragmentos del Caribe y de la ciudad continental, nos regala una visión en retrospectiva de la afectividad, que ha sido atravesada por las transformaciones sociales y políticas de una época.

Las distintas dimensiones de un texto permiten su apreciación de forma integral. La primera de ellas es la de lo evidente, lo que es posible contemplar, palpar. Por esa razón, empiezo por evidenciar el cuidado editorial de este libro, que permite al lector perderse, centrarse y dejarse llevar por cada 
verso, por las sensaciones que habitan el texto. El poemario, como en una pasarela de modas, luce de cuerpo entero, rotundo y contundente, gracias a un preciso diseño. Además, la portada es una maravilla que, a cada página, va quedando perene en la memoria. La imagen puede retratar cualquier esquina de Santiago de Cuba o de La Habana y, quizá, más sitios del Caribe insular. Esa ilustración recuerda lo universal, no solamente de la poesía, sino de las emociones que nos regala la autora en cada poema de Últimos días de un país.

Por otro lado, puedo dilucidar algunos temas centrales que unen cada texto de la obra. El primero de ellos es la nostalgia, que también se cuela en diversos aspectos de la vida común, de la tragedia cotidiana que se narra bellamente. Podría entonces hablar de más nostalgias, la de una casa que nunca más será como fue, la de la reunión familiar suspendida, la de la arquitectura que se ha ido con el paso de los años y también la de la historia que le ha pasado por encima.

Leo en estas líneas la añoranza de un país que dejó de ser propio, que se escapó del recuerdo, que ha traicionado el habitus de una sociedad entera para convertirse en utopía, que no se puede amar pero que atraviesa cada acto de la vida y la periodiza haciendo que sus años sean clasificados en un antes o un después del país.

La otra nostalgia es la que construye la memoria, cuyos caminos son inciertos y que selecciona arbitrariamente aquello que ha de acompañarnos para siempre. Únicamente es real para quien la posee y la enuncia, constituye también el fragmento de una memoria mucho más grande, aquella que de manera colectiva ha de construir el testimonio de una sociedad tan peculiar como la cubana posrevolucionaria. Esta memoria ha sido desterrada por la historia para abrir paso a la retórica del héroe y su maquinaria ideológica que, aún en estos días, permanece flotando cual fantasma que se reúsa a habitar su lugar: el de los muertos.

Otro tópico es la pérdida, que llega de la mano del exilio, del destierro. Se trata de la huida de un país que devora, que amenaza con tragar, con transformar en insectos a quienes enuncian aquello que no es justo. Además, está el extravío de los recuerdos, la conciencia de que jamás se habrá de volver a la casa materna, a la familia conocida, a las calles que fueron propias.

Y de pronto me veo en una sala de aeropuerto con una caja de cartón entre las manos.

Adentro laten las casas que habité

y las que aún no conozco.

$[\ldots]$ 
De pronto canto y luego callo y luego lloro

bajo mi propia sombra

transmigrando $(52-53){ }^{1}$

El exilio se dibuja mediante una maleta hecha con prisa y una voz que no sabe seleccionar entre lo que ha de llevar consigo y lo que, forzosamente, abandonará. Esa sensación de pérdida no es voluntaria y tampoco es la que resulta de una mala decisión de vida; se trata de una vuelta de tuerca en la narración de otros.

\author{
Esa mujer que arrastra la valija \\ se detiene a sopesar lo que ha empacado \\ cuánto llenan un par de calcetines \\ o un blusón \\ ese cuadro vacío que es la vida (29).
}

Las personas emigran para sobrevivir, en este caso, al sitio que las engulle. Y, sin embargo, este país irá siempre en la memoria, en la tradición y religiosidad afrocubana que permea todos los niveles de la sociedad.

El mar resulta el componente en que todo se une: la nostalgia, la memoria, el reclamo y la soledad.
Sobre el agua
flotan la madera y los recuerdos
sobre la mesa los adornos
mil relojes con la misma hora.
Detrás de cada puerta acecha un hombre
pero hay cosas que no recordarás
lo que pasó tras el telón de la inocencia (39).

Para cerrar el poemario, la autora nos regala unas líneas que denotan la esperanza, la reconstrucción del yo, la creación de una patria que no pueda devorarnos:

\section{Rozan sus manos \\ las muchachas \\ en el Metro \\ bajo las uñas}

polvo

pasión de un beso que no dan.

1 Todas las citas pertenecientes a Últimos días de un país corresponden a Alonso (2019), por lo cual sólo se anota el número de página. El libro a texto completo se se encuentra disponible en: http://ri.uaemex.mx/handle/20.500.11799/100111 
Retumba en sus oídos el sonido de los vidrios

el golpe en el metal

madrugada de soldados y de piedras

de voces que tratan de acallar al miedo.

Volverá el peregrinar sin prisa

y sin escombros

amaneceres en ciudad amartelada

enfebrecida el agua

la sangre en la nariz.

Volverán esas tardes soñando junto al mar

paseos

alcohol

bailes salvajes

y cantarán

tomadas de la mano (57).

La poesía es, entonces, un viaje que nos permite la restauración de la memoria, la construcción de nuevos horizontes, la conquista de otras tierras, como hizo Colón en su carabela. Y, como decía Rilke, se viaja para volver, ¿a dónde?, a la patria, pero no aquella que se mide en extensión de territorio sino la de la memoria, la que nos da significado, identidad y pertenencia.

Si me preguntaran de qué color es Últimos días de un país, tendría que decir que es de un azul opaco. Al final, empieza a tener algún tinte luminoso que no olvida la trágica huida y siempre llevará a cuestas un poco de borrasca del pasado. Creo que resulta imprescindible en estos años leer poesía, escribirla, sentirla, detenernos cuando alguien la grita a media calle, en una carpa, en una librería. Nuestra realidad convulsa se construye con sus fragmentos, quizá sea amarga pero siempre será poesía.

Aída Chacón Castellanos. Licenciada en Lengua y Literatura Hispánicas por la Universidad Nacional Autónoma de México (UNAM), México. Actualmente, es estudiante del Doctorado en Estudios Latinoamericanos de la UNAM. Su narrativa y poesía se han publicado en varias revistas impresas y digitales de México, Argentina, España, Costa Rica y Estados Unidos. Es autora del libro de cuentos Agua ardiente (Kapelmex, 2009). Tiene el blog de poesía y narrativa Libélula sobre acuarela. 